Recep Tayyip Erdoğan Universitesi Sosyal Bilimler Dergisi / Recep Tayyip Erdoğan University Journal of Social Sciences / Haziran 2021 / Cilt: 8 / Sayı: 13

Sayfa: $82-94$

Kaynakça Gösterimi / Citation:

APA: Bilici, İ. (2021). The relation between environmental change and environmental refugees: The case of Asia. Recep Tayyip Erdoğan Üniversitesi Sosyal Bilimler Dergisi, 8(13):

82-94.

https://doi.org/10.34086/rteusbe.938600

Chicago: Bilici, İlhan. "The relation between environmental change and environmental refugees: The case of Asia.” Recep Tayyip Erdoğan Üniversitesi Sosyal Bilimler Dergisi. 8/13 (2021): 82-94.

\title{
THE RELATION BETWEEN ENVIRONMENTAL CHANGE AND ENVIRONMENTAL REFUGEES: THE CASE OF ASIA
}

Çevresel Değişim ve Çevre Mültecileri Arasındaki İlişki: Asya Örneği

İlhan BİLİCi

Arş. Gör., Recep Tayyip Erdoğan Üniversitesi, İ.İ.B.F., Siyaset Bilimi ve Kamu Yönetimi Bölümü, ilhan.bilici@erdogan.edu.tr

ORCID: 0000-0002-4085-7274

Makale Bilgisi / Article Information

Makale Türü / Article Types: Araştırma Makalesi / Research Article

Geliş Tarihi / Received: 17 Mayıs / May 2021

Kabul Tarihi / Accepted: 4 Haziran / June 2021

Yayımlanma Tarihi / Published: 30 Haziran / June 2021

İntihal: Bu makale araştırma ve yayın etiğine uygun şekilde hazırlanmış ve turnitind intihal taramasından geçmiştir.

Copyright $\odot$ Published by Recep Tayyip Erdoğan Üniversitesi, Lisansüstü Eğitim Enstitüsü / Recep Tayyip Erdoğan University, Institute of Graduate Studies, Rize, 53100 Turkey. All rights reserved. E-ISSN: 2149-223 
Recep Tayyip Erdogan Universitesi Sosyal Bilimler Dergisi / Recep Tayyip Erdoğan University Journal of Social Sciences / Haziran 2021

/ Cilt: 8 / Say1: 13

Sayfa: $82-94$

\begin{abstract}
In today's globalized world, it is seen that the displaced population reached a level that can be interpreted as the highest value in the human history. Thus, various researchers have conducted studies to theorise the concept of the displaced people and migration. Because scholars and policy-makers have not agreed on the fact that environmental change has affected the displaced people and hence, they should be classified as "Environmental Refugees" and given refugee status, the topic in question is evaluated as problematic. The current paper focuses on this argument and discusses how environmental change has influenced migration in Asia in which half of the world's population reside, and economic and social changes occur in a short time and at a great rate. The paper also explains the "Environmental Refugees" term and argues that the term can be used to describe people who have left their origins because of environmental change.
\end{abstract}

Keywords: Asia, Emigration, Environmental Refugees, Environmental Change.

Öz: Günümüzün küreselleşen dünyasında yerinden edilmiş nüfusun insanlık tarihinin en yüksek değeri olarak yorumlanabilecek bir düzeye ulaştığ görülmektedir. Bu nedenle, çeşitli araştırmacılar yerinden edilmiş insanları ve göç kavramını teorileştirmek için çalışmalar yürütmüştür. Akademisyenler ve politikaya yön verenler, çevresel değişimin yerlerinden edilmiş insanları etkilediği ve dolayısıyla "Çevre Mültecileri" olarak sınıflandırılmaları ve mülteci statüsü verilmesi gerektiği konusunda hemfikir olmadıkları için söz konusu konu sorunlu olarak değerlendirilmektedir. Bu makale bu argümana odaklanmakta ve çevresel değişimin dünya nüfusunun yarısının ikamet ettiği ve ekonomik ve sosyal değişimlerin kısa sürede ve büyük oranda meydana geldiği Asya'da göçü nasıl etkilediği tartışmaktadır. Makale ayrıca "Çevre Mültecileri” terimini açıklamakta ve bu terimin çevresel değişim nedeniyle kökenlerini terk eden insanları tanımlamak için kullanılabileceğini savunmaktadır.

Anahtar Kelimeler: Asya, Göç, İklim Mültecileri, Çevresel Değişim. 


\section{INTRODUCTIVE CONSIDERATIONS}

Scholars and activists have theorised a connection between environmental change and migration (Massey, Axinn, \& Ghimire, 2010). That is why there has been an on-going debate among them over whether environmental change leads to the displacement of millions of people as "environmental refugees" or "environmental migrants" (Black, Adger, Arnell, Dercon, Geddes, \& Thomas, 2011, p. $3)$. According to a paper published by the AAAS in 2011, 50 million environmental refugees are expected to exist by the 2020s (Black et al., 2011). Myers (1997) claims that there would be 200 million people displaced as a direct result of environmental change caused by climate change and environmental degradation. Others believe that migration caused by environmental change is "not a problem but symptoms"; the problem has been portrayed as a "continuing economic and population growth on a finite planet" (Heinonen, 2013, p. 200).

It has also been said that even though environmental factors have an impact on migration, they are interlinked with a variety of political, social and economic dynamics. Focusing on the environmental factors by disregarding these dynamics does not broaden the understanding of particular circumstances of population displacement (Castles, 2002). In other words, some studies advocate that "environmental factors and climate change" have been seen as key push factors of migration, whilst others believe that "population displacements, forced migrations, and abandonment of settlements" will come as a result of the "current trends in population growth and global environmental change" (McLeman, 2011, p. 108). That is, there is no agreement among scholars regarding how to describe the issue (Warner, Hamza, Oliver-Smith, Renauld, \& Julca, 2009). It has been stated that this lack of agreement has been caused by the scarcity of good data on the subject (Massey et al., 2010).

It is a common assumption that, throughout human history, people have migrated in order to survive natural disasters. From a historical perspective, the vast majority of migration resulted from environmental change has took place within and between states (Hugo, 1996). In other words, there has been a strong relationship between human displacement and environmental change; people are forced to migrate to other countries, or to another region within the same country, because of environmental issues (Geddes, Adger, Arnell, Black, $\&$ Thomas, 2012). This is because an increasing number of persons are no longer able to benefit from a safe environment in their places of origin, owing to "drought, soil erosion, desertification, 
deforestation and other environmental problems" (Myers, 1997, p. 167; Warner et al., 2009). While many people have been able to flee their countries, others have been displaced within their own countries (Myers, 1993).

This paper will discuss how environmental change has influenced migration in the context of Asia. Besides, it will explain the concept of "Environmental Refugees" and how this term can be used to describe people who had to move from their origins because of the extremely unfortunate situations that environmental change has resulted in (Bilici, 2017). The reason why the paper focuses on the Asia region is two-folded: it consists of more than half of the world's populace and it is undergoing rapid economic and social change (Hugo, 1996). The paper firstly seeks to examine whether people fleeing their countries because of environmental change can be categorized as environmental refugees or not in international law. It secondly moves on to articulate the role that climate change plays in migration. It then explains how environmental degradation influences migration. The paper finally concludes by summarizing and giving future recommendations.

\section{A GROWING FACT OF THIS GLOBALIZED ERA: ENVIRONMENTAL REFUGEES}

This part of the paper explains the term "environmental refugee" by analysing the relationship between "refugee" and "environmental refugee" and then offers some reasons why the term has been not recognized juristically, although it has been commonly used in academia.

Many people have been compelled to leave their home areas for a variety of reasons, including both natural and anthropogenic. Natural drivers for abandoning places of origin temporarily involve "unanticipated earthquakes, volcanic eruptions, flooding, and drought", whilst anthropogenic drivers for persons to be forced involve "war, which could be both interstate and civil, racial or religious persecution, and political oppression" (Westing, 1992, p. 201). Those who leave their place of origin because of natural reasons are defined as environmental or climate refugees or environmental or climate migrants, whereas those who are forced to leave because of anthropogenic reasons are described as refugees (Waldinger, 2015). This paper refers to persons compelled to leave their places of origin because of environmental change as "environmental refugees" in proportion to the definition offered by El-Hinnawi. Moreover, environmental refugees are conceptualized throughout the paper to 
include those who are compelled to migrate in order to protect their livelihoods, because these groups have encountered hardship as a result of environmental changes (Massey et al., 2010). Indeed, it has been suggested by evidence from the recent past, and from the course of human history, that changes in environmental situations have contributed to the abandonment of human settlements (McLeman, 2011).

The 1951 Convention provides the definition for the term "refugee", which was revised by the 1967 Protocol and the Status of Refugees. As described by the 1951 Refugee Convention, a refugee is someone who "owing to a well-founded fear of being persecuted for reasons of race, religion, nationality, membership of a particular social group or political opinion, is outside the country of his nationality, and is unable to, or owing to such fear, is unwilling to avail himself of the protection of that country" (UNHCR, n.d.). What stands out from this definition is that: the person must be outside the place of origin of his or her nationality; they must run the risk of being prosecuted; the risk of persecution must be implemented because of his or her race, religion, membership of a particular social group, or political opinion; and the risk of being prosecuted must be a well-founded (Warner et al., 2009). That is to say, the word "refugee" has been associated with political repression, turmoil, civil strife and war (Islam, 1992). By doing so, the term "environmental refugees" does not fall within the terms of the 1951 Refugee Convention (Keane, 2003). That is, in international refugee law, a basis for international protection is not constituted by environmental conditions such as drought, flood, or loss of income caused by deforestation (Suhrke, 1994; Warner et al., 2009). In terms of the issue, it is necessary to look into the term "environmental refugee".

The term "environmental refugees" was coined by Lester Brown in 1970. Later, in 1985, a new class of people known as "environmental refugees" was identified and described by El-Hinnawi, under the umbrella of the United Nations Environment Programme [UNEP] (Massey et al., 2010) and this term has entered common usage in academia (Hugo, 1996). According to El-Hinnawi's definition, environmental refugees are defined as those compelled to abandon their places of origin, forever or temporarily, due to an environmental disruption--natural or man-made-that threatens their survival and affects the value of their life and well-being in a crucial way (as cited in Bates, 2002; Hugo, 1996; Keane, 2003; Massey et al., 2010; Westing, 1992). There are four key parts to this definition: (1) shortterm displacement because of short-term environmental changes such as an earthquake or industrial accident; (2) long-lasting displacement because of long-lasting environmental changes such as the creation of 
a lake or dam; (3) short-term or long-lasting displacement because of a decrease in the quality of life or well-being (Westing, 1992).

It is instructive to note that the reason why the word "refugee" has been associated with an amount of environmentally related population movements is imbedded in sociological reasoning, not legal ones (Suhrke, 1994). In the literature, a refugee is seen as somebody who is compelled to escape involuntarily, and this unwillingness to abandon their places of origin renders the refugee powerless and vulnerable (Suhrke, 1994). In other words, the refugee feels he or she has no option but to flee, in order to secure his or her livelihood (Myers, 2002). There are 120 million internal migrants, and at a minimum, 6 million deserve to be seen as environmental refugees, having been compelled to leave their cultivated lands because of agricultural development following decades of population growth (Suhrke, 1994). In addition, there are 50 million people-a figure increasing by 10 million every year--displaced involuntarily by public work projects such as large dams being built in China and India. Although most of those affected by the construction were resettled elsewhere, more than one million remain in a refugee-like situation (Suhrke, 1994). One might wonder why people who remain in such situations cannot be seen as refugees. The answer is two-folded: one is, as noted earlier, that there is no clear definition for migration that has resulted from environmental change, because of the difficulty in separating environmental dynamics from other reasons of migration such as economic and social. The other reason is that the scope of acceptable reasons for immigration and rises in the number of immigrants is not extended by policy makers of the most developed countries because it is not in their political interest (Waldinger, 2015).

\section{A. The Effects of Climate Change as An Environmental Change on Migration in Asia}

This part of the paper articulates climate change and its highly likely effects on migration in Asia, in three interlinked ways: namely sea-level rise, changes in rainfall regimes, and tropical cyclones.

It is a truism that climate change is expected to become an important dynamic in bringing about environmental migration in Asia (Hugo, 1996; Warner et al., 2009). For this reason, it has been seen as a threat to human security that will cause the displacement of millions of persons as environmental refugees (Heinonen, 2013). Increases in the concentration of greenhouse gases in the atmosphere drive global climate change, which exhibits itself in alterations to weather patterns, as well as an increase in sea level, from the expansion of 
thermal sea-water and the melting of land ice (Black et al., 2011). It has been estimated that once global warming takes place, as many as 200 million people could be displaced "by sea-level rise and coastal flooding, by disruptions of monsoon systems and other rainfall regimes, and by droughts of unprecedented severity and duration" (Myers, 2002, p. 609). It has also been estimated that climate change will cause a significant population displacement between the years 2040 and 2060, particularly in coastal areas (Warner et al., 2009). Even though these would-be affected areas constitute just 2 percent of the earth's land surface, these areas are inhabited by 10 per cent of the existing world population, and 13 per cent of the world's urban population. Approximately 75 per cent of these affected residents will be those living in low-lying areas in Asia (Warner et al., 2009). Persons who are compelled to abandon their places of origin immediately, or in the near future, because of sudden or gradual changes in their places of origin, are associated with - at a minimum - three aspects of climate change, namely: sea-level rise, changes in rainfall regimes, and tropical cyclones. These environmental changes that are expected to cause significant displacement are articulated below.

One of the most significant effects of climate change is perhaps a rise in sea level. An increase in sea level could bring about the erosion of coastal land and the destruction of ecosystems, as well as soil salinization within low-lying agricultural land (Black et al., 2011). The worst consequence of sea-level rise is a permanent loss of land and thereby the forced displacement of people (Black et al., 2011; Waldinger, 2015). An official paper from the International Panel on Climate Change (IPCC) projected at the time of publication (2007) that the sea level will rise between 0.2 to 0.5 meters by the year 2100 . However, today, the high end of that range has already been met or exceeded, which suggests that the sea level will rise by as much as one meter or more by the year 2100 (Heinonen, 2013). This suggests that a greater number of people than originally thought will be displaced in the near future.

Coastal populations, particularly in China, India and Bangladesh, are in jeopardy. In the worst-case scenario, between 13\% and $15 \%$ of the population in Bangladesh could be relocated between 1994 and 2050 (Suhrke, 1994). If the displacement happens gradually, initially between 200,000 and 300,000 persons could be displaced yearly (Suhrke, 1994). It has been estimated that the total amount of persons at risk of being displaced because of rising sea levels could be 73 million in China and 20 million in India (Myers, 2002). 
Another important effect of climate change is possible changes in rainfall patterns. A rise or fall in rainfall can lead to an increased risk of river flooding, a higher likelihood of a fire, more incidences of drought - which affects agriculture and industry - and also alters the productivity of crop and pasture, which could eventually lead to failing crops (Black et al., 2011). An example of how unusually high levels of rainfall can affect the environment can be found in India. Exceptionally heavy rains - a meter of which fell in one day - hit Mumbai in 2005. It caused flooding in the city, and persons dwelling in slums and low-lying places were especially affected. In the periurban regions of Mumbai, more than 60.000 villagers were displaced because the flooding destroyed a year's worth of crops (Geddes et al., 2012). It has been estimated that, by the year 2030, a significant number of people living in rural parts of India will be displaced because of an increased likelihood of floods in these areas (Geddes et al., 2012).

The intensity or frequency of cyclones is another way in which climate change may affect migration (Black et al., 2011). Tropical cyclones-which have resulted in heavy destruction of infrastructure and significant fatalities in the past-- are expected to rise in accordance with climate change (Waldinger, 2015). The quintessential example of environmental displacement can be seen in Bangladesh, where there is an extremely dense population and vulnerability to cyclones (Castles, 2002). The most severe cyclone of the century hit the country in 1970. It claimed around half a million lives. It led to the existence of many environmental refugees who were forced to leave their places of origin (Islam, 1992). Most recently, in 1991, a cyclone struck the coastal zone, claiming more than 200,000 lives and creating many refugee-like situations (Myers, 1993).

\section{B. The Effects of Environmental Degradation on Migration in Asia}

This part of the paper seeks to explain environmental degradation and its impact on migration in Asia, by focusing on two main issues - land and water degradations, which are vital to human life.

In addition to climate change, migration is driven directly by environmental degradation (Black et al., 2011). Even though environmental change triggers migration, the effects of environmental degradation are perhaps best understood by analysing the role it plays in other systems (Geddes et al., 2012). In other words, because migration is complex and multi-casual, so determining how 
environmental degradation affects migration independently from other dynamics - economic, social and demographic, for example -is a very complex and difficult task (Massey et al., 2010; Suhrke, 1994; Warner et al., 2009). This is the case in China and India, where the key driver of migration is triggered by economic reasons and it is related to important social and economic changes (Geddes et al., 2012).

It has been said that various methods of environmental degradation are slow-onset progresses that exceed a level at which the harm might be irrevocable (Suhrke, 1994). Forced and possibly massive population displacement could occur as a direct result of such degradation (Suhrke, 1994). Those persons, who move to another part of their country or to a neighbouring country to seek better economic conditions, might have been living in poverty that has been caused by environmental degradation. This is the case for many environmental refugees in various subcontinents of India (Myers, 1993).

One of the most important effects of environmental degradation on migration is perhaps land degradation. Land degradation is regarded as a push factor for the displacement of many people. It is the decline in the quality of land that is being used for agriculture and delivery of the ecosystem services. This degradation results from a mixture of agricultural methods, extreme weather incidents and climate change patterns (Black et al., 2011). Since land situations deteriorate, animals such as cattle are slayed, seeds are used up, and the lands are left. People who remain have to move to relief camps or urban squatter neighbourhoods, which could be described as a refugee-like condition (Suhrke, 1994). This is because the habitat is no longer compatible with their continued residence (Bates, 2002). It is also worth noting that an increase in population has contributed to pressure on agricultural land, even though fertility falls have happened in Asia. That is why many people-who have compelled to dwell in cultivating marginal places-- are vulnerable to erosion, desertification and other degradations (Hugo, 1996).

Another problematic issue arisen out of environmental degradation is water degradation. It has been estimated that water tables are on the decline in many countries in Central Asia, where desertification is on the rise (Heinonen, 2013). The advance of deserts drives many people to mountainous areas in order to secure their livelihoods, giving rise to the tide of environmental refugees in countries such as Afghanistan (Heinonen, 2013). It is also worth noting that water scarcity will be unfavourable for agriculture, particularly irrigation agriculture, as well as for household use. With all that said, it might result in more people contracting illnesses caused by dehydration (Myers, 1997). 
It is highly likely that climate change has a negative effect on water scarcity with regards to coastal and marine degradation (Warner et al., 2009). Its impact can be seen in the loss of species and habitats that have been caused by the degradation of coastal and marine ecosystems (Black et al., 2011). These ecosystems are regarded as vital to the source of income of women, particularly in India where almost half of the fishery workforce consists of women (Badjeck, Allison, Halls, \& Dulvy, 2010). In this sense, it is fair to say that coastal degradation jeopardizes the livelihood of many Indian women, which might cause displacement as from the loss of fishing grounds, coastal degradation and water scarcity (Badjeck et al., 2010).

\section{CONCLUSION}

The paper has examined the likely effects of environmental change in the context of developments in Asia. It concludes that the term "environmental refugee" can be used to describe people who are forced to leave their places of origin for the purpose of securing their lives because of natural or man-made life-threatening disasters. Although the term has not been recognized in international law, it has gained a wide usage in academia. Meanwhile, it is useful to note that the subject of environmental refugees could be a growing phenomenon of foremost human crises of $21^{\text {st }}$ century in a greenhouse-affected world (Heinonen, 2013; Myers, 1993; 1997; 2002).

In addition, it concludes that the effects of climate change and environmental degradation did and will bring about millions of displacement of people in Asia (McLeman, 2011). Those living in lowlying lands in Asia will be the most affected by the sea-level rises and increased risk of flooding caused by global warming. Environmental degradation caused will also affect Asian citizens who rely heavily on fishing and agriculture for their livelihoods. Therefore, it is safe to say that climate change and environmental degradation will play a greater and greater role on migration in Asia in the future, as climate change worsens.

In this sense, it is necessary to note that the effects of climate change and environmental degradation are interlinked and they trigger one another. Even though environmental change affects the traits of future migration, it will depend on both the environmental change and how other causes such as economic and social of migration alter over a given time (Black et al., 2011). As Asian countries are going through rapid social and economic changes, it is difficult to determine decisively whether reasons of migration are because of environmental reasons or because of these other factors. 
Recep Tayyip Erdogan Universitesi Sosyal Bilimler Dergisi / Recep

Tayyip Erdoğan University Journal of Social Sciences / Haziran 2021

/ Cilt: 8 / Say1: 13

Sayfa: $82-94$

However, even if people do migrate to seek better economic or social conditions, the poor conditions they were living in in the first places are, in many cases, caused by environmental degradation. It is likely that the continuation of environmental degradation and global warming will worsen economic and social conditions for many persons in Asia in the future, forcing more people to leave their places of origin.

The paper has examined the topic briefly. Further research and practice are essential to be carried out by using representative data (Massey et al., 2010). Researchers should seek to obtain data on how environmental change affects migration, and work on defining the different types of environmental migration and their effects.

In the event of catastrophic environmental change, in which the land is uninhabitable, or has disappeared because of a rise in sea level, future research should focus on the improvement of resettlement processes (Warner et al., 2009). Moreover, as the issue of environmental refugees has been associated with environmental change, and in many cases has been found to be a major migration push factor, this problem should be recognized by both traditional refugee organizations and other organizations such as United Nations Population Fund [UNPF], United Nations Development Programme [UNDP] (Westing, 1992). The essay, therefore, concludes that persons leaving their place of origin because of environmental reasons should be recognised as environmental refugees by international law. 
Recep Tayyip Erdogan Universitesi Sosyal Bilimler Dergisi / Recep

Tayyip Erdoğan University Journal of Social Sciences / Haziran 2021

/ Cilt: 8 / Say1: 13

Sayfa: $82-94$

\section{REFERENCES}

Badjeck, M. C., Allison, E. H., Halls, A. S., \& Dulvy, N. K. (2010). Impacts of climate variability and change on fishery-based livelihoods. Marine Policy, 34(3), 375-383.

Bates, D. C. (2002). Environmental refugees? Classifying human migrations caused by environmental change. Population and Environment, 23(5), 465-477.

Bilici, İ. (2017). The effect of environmental change on human migration in the context of Asia [Conference presentation abstract]. XIV. European Conference on Social and Behavioral Sciences, Odesa, Ukraine.

Black, R., Adger, W. N., Arnell, N. W., Dercon, S., Geddes, A., \& Thomas, D. (2011). The effect of environmental change on human migration. Global Environmental Change, 21, 3-11.

Castles, S. (2002). New issues in refugee research. Environmental change and forced migration: making sense of the debate. Working Paper No.70. Erişim adresi http:/ / www.unhcr.org/3de344fd9.html

Geddes, A., Adger, W.N., Arnell, N.W., Black, R., Thomas D.S.G. (2012). Migration, environmental change, and the challenges of governance. Environmental and Planning C: Government and Policy, 30(6), 951-967.

Heinonen, M. (2013). Migration and the false promise of growth. On The Horizon-The Strategic Planning Resource for Education Professionals, 21(3), 197-208.

Hugo, G. (1996). Environmental concerns and international migration. International Migration Review, 30(1), 105-131.

Islam, M. (1992). Natural calamities and environmental refugees in Bangladesh. Refuge: Canada's Journal on Refugees, 5-10.

Keane, D. (2003). The environmental causes and consequences of migration: A search for the meaning of environmental refugees. Georgetown International Environmental Law Review, 16, 209-223.

Massey, D. S., Axinn, W. G., \& Ghimire, D. J. (2010). Environmental change and out-migration: Evidence from Nepal. Population and Environment, 32(2-3), 109-136. 
Recep Tayyip Erdogan Universitesi Sosyal Bilimler Dergisi / Recep

Tayyip Erdoğan University Journal of Social Sciences / Haziran 2021

/ Cilt: 8 / Say1: 13

Sayfa: $82-94$

McLeman, R. A. (2011). Settlement abandonment in the context of global environmental change. Global Environmental Change, 21, 108-120.

Myers, N. (1993). Environmental refugees in a globally warmed world. Bioscience, 43(11), 752-761.

Myers, N. (1997). Environmental refugees. Population and Environment, 19(2), 167-182.

Myers, N. (2002). Environmental refugees: a growing phenomenon of the 21st century. Philosophical Transactions of the Royal Society of London. Series B: Biological Sciences, 357(1420), 609-613.

Refugees. (1 Nisan 2016). Erişim adresi http:/ / www.unhcr.org/pages /49c3646c125.html

Suhrke, A. (1994). Environmental degradation and population flows. Journal of International Affairs, 47(2), 473-496.

Waldinger, M. (2015). The effects of climate change on internal and international migration: implications for developing countries. Grantham Research Institute on Climate Change and the Environment, 217.

Warner, K., Hamza, M., Oliver-Smith, A., Renauld, F., \& Julca, A. (2009). Climate change, environmental degradation and migration. Natural Hazards, 5(3), 689-715.

Westing, A. H. (1992). Environmental refugees: a growing category of displaced persons. Environmental Conservation, 19(3), 201207. 